\title{
T45G Adiponectin Gene Polymorphism and its Association with Hyperglycemia in Adult Filipinos Seen at the Philippine General Hospital - A Pilot Study
}

\author{
Elizabeth Paz-Pacheco, ${ }^{1}$ Eva Maria Cutiongco-dela Paz ${ }^{2}$ and Angelique Bea C. Uy ${ }^{1}$ \\ ${ }^{1}$ Division of Endocrinology, Diabetes, and Metabolism, Department of Medicine, College of Medicine and Philippine General Hospital, University of the Philippines Manila \\ ${ }^{2}$ National Institutes of Health, University of the Philippines Manila
}

\begin{abstract}
Introduction. Adiponectin is an adipocytokine known to have anti-inflammatory and anti-atherogenic effects. It appears to impact insulin resistance and the subsequent development of type 2 diabetes mellitus (T2D). The gene encoding adiponectin ADIPOQ, has single nucleotide polymorphisms (SNPs) that can be useful biomarkers to predict development of T2D; with the T/G polymorphism of SNP +45 in exon 2 being the most common.
\end{abstract}

Objective. This study was conducted to evaluate the association of T45G adiponectin gene polymorphism with hyperglycemia among adult Filipinos seen at the outpatient department of the Philippine General Hospital.

Methods. This is a matched case-control study, with duration of 12 months. DNA was extracted using the QIAGEN MIDI Blood Extraction Kit. The genomic DNA obtained was then subjected to real time PCR for SNP detection.

Results. One hundred (100) adults were enrolled; forty-three (43) had normoglycemia, while fifty seven (57) had hyperglycemia, after a $75-\mathrm{g}$ oral glucose tolerance test. Hyperglycemic subjects were older (44 \pm 15.6 years vs. $52 \pm 8.3$ years, $p$-value 0.002), and had lower HDL levels (58.5 $\pm 16.0 \mathrm{mg} / \mathrm{dLvs}$. $47.8+11.8 \mathrm{mg} / \mathrm{dL}$, $\mathrm{p}$-value 0.000 ). Among thirty-nine (39) participants found to have the T45G adiponectin gene polymorphism, 22 or $56.4 \%$ were hyperglycemic while 17 or $43.6 \%$ were normoglycemic.

Conclusion. There was no significant association observed between the T45G SNP and presence of hyperglycemia.

Key Words: T45G polymorphism, adiponectin, hyperglycemia

\section{INTRODUCTION}

Corresponding author: Elizabeth Paz-Pacheco, MD Division of Endocrinology, Diabetes, and Metabolism Department of Medicine Philippine General Hospital University of the Philippines Manila Taft Avenue, Manila 1000, Philippines Email: eppacheco@gmail.com
Adiponectin is an adipocytokine primarily produced by adipocytes but also expressed in the pituitary gland, liver, diencephalon, skeletal muscle, ovary, spleen, and kidney. It is known to have anti-inflammatory, anti-atherogenic, and insulin-sensitizing effects. ${ }^{1-3}$ It accumulates in injured endothelium and dose-dependently inhibits the TNF- $\alpha$ signaling in human aortic endothelial cells, thus generating a vasculoprotective effect as this increases nitric oxide production. ${ }^{4,5}$ Hypoadiponectinemia is associated with coronary artery disease, hypertension, central obesity, and a greater risk of myocardial infarction. ${ }^{1,6}$ It appears to also impact insulin resistance as low adiponectin levels precede and predict type 2 diabetes ${ }^{7-9}$, while increasing plasma levels of adiponectin correlate with improved insulin sensitivity. ${ }^{10-12 .}$ This suggests potential therapeutic targets in the treatment of coronary artery disease, diabetes, and metabolic syndrome. 
The protective role of adiponectin against diabetes has been investigated in African-Americans, Pima Indians, Asian Indians, Japanese-Americans, Japanese, and Korean populations. ${ }^{13-18}$ In Filipinos living in San Diego, California, the lower levels of adiponectin may be contributory to the susceptibility to diabetes. ${ }^{19}$ Filipinos with diabetes living in the Philippines likewise were found to have significantly lower adiponectin levels compared with normoglycemic subjects. ${ }^{20}$

A considerable number of genetic components associated with T2D are polygenic in nature as what has been discovered in several genome-wide association studies. Genetic variants are currently being investigated for its predictive value in T2D. ${ }^{21}$ Because the accuracy of prediction relies on many factors, many additional common variants with small effect sizes or rare variants with stronger effect sizes must be further identified. Although investigational in nature, the information on genetic variants can be provided to patients to encourage patients to seek primary prevention, and to adopt a healthy lifestyle.

The gene encoding adiponectin $A D I P O Q$ or $A C D C$ or $A P M$ spans $16 \mathrm{~kb}$, contains three exons and two introns, and yields a $4.5-\mathrm{kb}$ mRNA transcript. ${ }^{22}$ This gene is found on chromosome $3 \mathrm{q} 27.17$ where the susceptibility loci for diabetes $^{23}$ and metabolic syndrome ${ }^{24}$ have been mapped. However, the association of $A D I P O Q$ gene SNPs with T2D and impaired glucose tolerance (IGT) or impaired fasting glucose (IFG) have been discordant in various populations. Among the most common reported variants is the $\mathrm{T} / \mathrm{G}$ polymorphism of SNP +45 in exon 2 (T45G). This T45G polymorphism has been shown to be associated with diabetes and obesity in some Japanese ${ }^{25}$, French Caucasians ${ }^{26,27}$, Swedish Caucasians ${ }^{28}$, and Chinese subjects ${ }^{29}$. In contrast, in a series of cross-sectional studies, no such relationship has been observed in Pima Indians ${ }^{30}$, another group of Japanese $^{31}$, and Korean subjects ${ }^{32}$.

This was the first investigation in a Filipino population to determine the association of $\mathrm{T} 45 \mathrm{G}$ adiponectin gene polymorphism with hyperglycemia. A significant association may be exploited further in the search for novel approaches to the treatment and/or prevention of diabetes mellitus and the metabolic syndrome in Filipinos.

The general objective of this study was to evaluate the association of T45 $\mathrm{G}$ adiponectin gene polymorphism with the presence of hyperglycemia among adult Filipinos seen at the outpatient department of the Philippine General Hospital. The specific objectives were 1) to determine the genotype frequencies for the $\mathrm{T} 45 \mathrm{G}$ adiponectin gene polymorphism of adult hyperglycemic and normoglycemic Filipinos; and 2) to determine the T45G genotype which is associated with the presence of hyperglycemia among enrolled subjects matched for age, sex, and body mass index (BMI).

\section{METHODS}

\section{Study Design}

This matched case-control study had duration of 12 months. Adult Filipinos (age 18 years and above) seen at the outpatient department of the Philippine General Hospital were enrolled. Subjects were divided into three groups using definitions recommended by the American Diabetes Association. The Control Group included patients with fasting plasma glucose $<100 \mathrm{mg} / \mathrm{dL}$ and 2-hour post-75 g anhydrous glucose random plasma glucose $<140 \mathrm{mg} / \mathrm{dL}$, no past medical history of diabetes mellitus, and no family history of diabetes mellitus in the first- or second- degree relatives. The Pre-diabetic Group consisted of patients with fasting plasma glucose $\geq 100$ but $<126 \mathrm{mg} / \mathrm{dL}$ and/or 2 -hour post $-75 \mathrm{~g}$ anhydrous glucose random plasma glucose $\geq 140$ but $<200 \mathrm{mg} / \mathrm{dL}$. The Diabetic Group was composed of patients with fasting plasma glucose $\geq 126 \mathrm{mg} / \mathrm{dL}$ and/or 2-hour post $75 \mathrm{~g}$ anhydrous glucose random plasma glucose $\geq 200 \mathrm{mg} / \mathrm{dL}$ or those who were previously diagnosed by their attending physician to have diabetes mellitus. Exclusion criteria were any of the following: 1) congestive heart failure as defined by Framingham criteria, 2) established renal disease requiring hemodialysis, or 3) patients on any of the following medications: angiotensin-converting enzyme (ACE) inhibitors, angiotensin-II receptor blocking agents, thiazolidinediones, or oral steroids.

For each case subject a control subject matched for age (within 10 years), BMI (within $1 \mathrm{~kg} / \mathrm{m}^{2}$ ), and sex was selected. When more than one control subject fulfilled the criteria, the subject most closely matched with BMI was chosen.

\section{Data Collection}

Patients were enrolled from the General Medicine, Family Medicine, and Diabetes clinics, Out-Patient Department of the Philippine General Hospital. They underwent fasting blood glucose and random plasma glucose 2 hours post-75 g OGTT determination. A case was classified as normoglycemic in the presence of the following: 1) fasting plasma glucose of $<100 \mathrm{mg} / \mathrm{dl}$ and 2-hour post-75-g anhydrous glucose random plasma glucose of $<140 \mathrm{mg} / \mathrm{dl}, 2$ ) absence of past medical history of diabetes, and 3) absence of family history of diabetes mellitus in the first- or second-degree relatives. Patients were classified as prediabetic if fasting plasma glucose was $\geq 100 \mathrm{mg} / \mathrm{dL}$ but $<126 \mathrm{mg} / \mathrm{dL}$ and/or 2-hour post-75-g anhydrous glucose random plasma glucose was $\geq 140 \mathrm{mg} / \mathrm{dL}$ but $<200 \mathrm{mg} / \mathrm{dL}$. A case was classified as diabetic in the presence of any of the following: 1) fasting plasma glucose of $\geq 126 \mathrm{mg} / \mathrm{dL}$ and/or 2-hour post-75-g anhydrous glucose random plasma glucose of $\geq 200 \mathrm{mg} / \mathrm{dL}$ or 2) previous diagnosis of diabetes mellitus by a physician.

Clinical characteristics such as weight $(\mathrm{kg})$, height $(\mathrm{cm}), \mathrm{BMI}$, waist circumference, hip circumference, waist to hip ratio, systolic blood pressure, and diastolic blood pressure were taken and recorded. The following laboratory 
examinations were done for each patient: fasting plasma glucose and 2-hour post-75 $\mathrm{g}$ anhydrous glucose random blood sugar, total cholesterol, triglyceride, LDL, HDL, and plasma adiponectin level.

\section{DNA Extraction}

After obtaining blood samples from patients and controls, DNA was extracted using the QIAGEN MIDI Blood Extraction Kit. The genomic DNA obtained was analyzed for the presence or absence of the T45G polymorphism by real time PCR.

\section{Molecular Genotyping Using Real-Time PCR}

Detection of the ADIPOQ T45G Polymorphism was performed using the Applied Biosystems Taqman ${ }^{\circledR}$ SNP Genotyping Assay for ADIPOQ rs2241766 and optimized for use with the Corbett Gene Rotor 3000. Prior to analysis, the optimized genotyping assay protocol was first verified using direct PCR sequencing (Macrogen Korea, Inc).

The Applied Biosystems Taqman ${ }^{\circledR}$ SNP Genotyping Assay consists of two primers specific for the region of interest, and two Taqman ${ }^{\circledR}$ Minor Groove Binder probeseach differently labeled, that are specific for the polymorphism being interrogated. Each TaqMan MGB probe contains: A reporter dye at the $5^{\prime}$ end of each probe: VIC ${ }^{\oplus}$ dye is linked to the 5 ' end of the Allele 1 probe, $\mathrm{FAM}^{\mathrm{TM}}$ dye is linked to the 5 ' end of the Allele 2 probe. A minor groove binder (MGB) at the 3 ' end of each probe increases the melting temperature (Tm) for a given probe length (Afonina et al., 1997; Kutyavin et al., 1997), which allows the design of shorter probes. Shorter probes result in greater differences in $\mathrm{Tm}$ values between matched and mismatched probes, producing robust allelic discrimination. Even single nucleotide mismatches between a probe and the target sequence reduce the efficiency of probe hybridization, which in turn reduces the amount of reporter dye cleaved from a quenched probe, thereby lowering the incidence of nonspecific signals (Applied Biosystems Taqman ${ }^{\circledR}$ SNP Genotyping Assays Protocol).

During PCR, each TaqMan ${ }^{\circledR}$ MGB probe anneals specifically to its complementary sequence between the forward and reverse primer sites. When the oligonucleotide probe is intact, the proximity of the reporter dye to the quencher dye results in quenching of the reporter fluorescence primarily by Förster-type energy transfer (FRET; Förster, 1948; Lakowicz, 1983). The DNA polymerase extends the primers bound to the template DNA and then cleaves only probes that are hybridized to the target. Cleavage separates the reporter dye from the quencher dye, which results in increased fluorescence by the reporter. The increase in fluorescence signal occurs when probes that have hybridized to the complementary sequence are cleaved. The fluorescence signal generated by PCR amplification-denoted by an allelic discrimination plot-indicates which alleles are present in the sample (Applied Biosystems Taqman ${ }^{\circledR}$ SNP Genotyping Assays Protocol).
Each reaction mixture consisted of 20X $\operatorname{Taqman}^{\circledR}$ SNP Genotyping Assay Mix, 2X Taqman ${ }^{\circledR}$ Genotyping Master Mix and genomic DNA from the sample (Applied Biosystems Taqman ${ }^{\circledR}$ SNP Genotyping Assays Protocol). Non-template controls and samples with known genotypes were run alongside the samples to ensure accuracy and consistency.

Before samples were processed en masse, results of the optimized Taqman ${ }^{\circledR}$ SNP Genotyping protocol were compared against the results of polymorphism detection by direct PCR sequencing using the forward and reverse primers 5'-TCT CTC CAT GGC TGA CAG TG-3' forward and 5'-CCT TTC TCA CCC TTC TCA CC-3' (Filippi, et al 2004) for verification.

\section{Data Processing and Analysis}

Genotype distributions were assessed if they were in Hardy-Weinberg equilibrium. Linkage disequilibrium analysis between the polymorphisms was calculated using the two-locus linkage disequilibrium calculator (available at http://www.iop.kcl.ac.uk/IoP/Departments/PsychMed/ GEpiBSt /software.shtml). The association of genotypes with continuous parameters was tested by ANOVA. Variables with skewed distribution were logarithmically transformed prior to analysis. Adjusted odds ratio (OR) associated with genotypes were calculated by conditional logistic regression analysis. Haplotype frequencies and differences in haplotype frequencies between phenotypes were estimated using Estimating Haplotype Frequencies Software (available at ftp://linkage.rockefeller.edu/software/ eh). A significant level of $5 \%$ is chosen for all tests $(p<0.05)$.

\section{Ethical Considerations}

The study was conducted according to the Declaration of Helsinki. Guidelines for Good Clinical Practice were also observed. The University of the Philippines-Manila Research Ethics Board approved the protocol. All subjects were given informed consent forms detailing the rationale and objectives of the study, the data collection and laboratory tests to be done, as well as the possible adverse effects from the laboratory tests. Only patients who were clinically stable, able to read and write, and of sound mind and capable of independent judgment were recruited. All participants were given genetic counseling before and after the tests.

\section{RESULTS}

A total of 100 subjects participated in this pilot study. Forty-three (43) subjects met the criteria as controls and were classified as normoglycemic. Fifty-seven (57) subjects fulfilled the criteria as pre-diabetic and diabetic groups and were classified as hyperglycemic. Table 1 shows the baseline characteristics of the recruited subjects. They differ significantly in age $(44 \pm 15.6$ years vs. $52 \pm 8.3$ years, p-value $0.002)$ and levels of fasting blood glucose $(88.7 \pm 6.2 \mathrm{mg} /$ 
Table 1. Baseline Characteristics of Subjects

\begin{tabular}{|c|c|c|c|}
\hline Variable & Normoglycemic $(n=43)$ & Hyperglycemic $(n=57)$ & p-value \\
\hline Age (years) & $44 \pm 15.6$ & $52 \pm 8.3$ & $0.002^{*}$ \\
\hline Sex & & & 0.650 \\
\hline Female & 33 (77\%) & $41(72 \%)$ & \\
\hline Male & $10(23 \%)$ & $16(28 \%)$ & \\
\hline Weight (kg) & $57 \pm 12.2$ & $58 \pm 11.7$ & 0.566 \\
\hline Height (m) & $1.6 \pm 0.08$ & $1.6 \pm 0.08$ & 0.673 \\
\hline $\mathrm{BMI}\left(\mathrm{kg} / \mathrm{m}^{2}\right)$ & $23.1 \pm 4.2$ & $23.6 \pm 4.1$ & 0.558 \\
\hline Waist Circumference $(\mathrm{cm})$ & $79.0 \pm 11.3$ & $83.3 \pm 11.0$ & 0.061 \\
\hline Hip Circumference $(\mathrm{cm})$ & $89.7 \pm 8.3$ & $92.2 \pm 9.0$ & 0.153 \\
\hline Waist:Hip Ratio & $0.88 \pm 0.07$ & $0.90 \pm 0.07$ & 0.086 \\
\hline Systolic BP (mmHg) & $118 \pm 15.0$ & $124 \pm 13.2$ & 0.050 \\
\hline Diastolic BP (mmHg) & $74 \pm 12.4$ & $77 \pm 8.3$ & 0.281 \\
\hline Smoking Status & & & 0.949 \\
\hline Non-Smokers & $36(84 \%)$ & $44(77 \%)$ & \\
\hline Current Smokers & $4(9 \%)$ & $2(4 \%)$ & \\
\hline Ex-Smokers & $3(7 \%)$ & $11(19 \%)$ & \\
\hline Fasting Blood Glucose (mg/dL) & $88.7 \pm 6.2$ & $132.9 \pm 42.5$ & $0.000^{*}$ \\
\hline 2-hr Random Blood Glucose (mg/dL) & $95.9 \pm 16.1$ & $183.5 \pm 67.5$ & $0.000^{*}$ \\
\hline Total Cholesterol (mg/dL) & $242.5 \pm 65.4$ & $228.8 \pm 63.2$ & 0.292 \\
\hline Triglyceride (mg/dL) & $162.5 \pm 43.5$ & $171.8 \pm 45.2$ & 0.301 \\
\hline $\mathrm{LDL}(\mathrm{mg} / \mathrm{dL})$ & $150.3 \pm 52.8$ & $141.3 \pm 54.9$ & 0.411 \\
\hline $\mathrm{HDL}(\mathrm{mg} / \mathrm{dL})$ & $58.5 \pm 16.0$ & $47.8 \pm 11.8$ & $0.000^{*}$ \\
\hline Plasma Adiponectin (ng/mL) & $38 \pm 16.2$ & $33 \pm 18.9$ & 0.151 \\
\hline
\end{tabular}

Table 2. Baseline Characteristics of Subjects

\begin{tabular}{lcccc} 
& Exposed TG & Unexposed TT/GG & Total & Proportion Exposed \\
Cases (Hyperglycemic) & 22 & 35 & 57 & 0.3860 \\
Controls (Normoglycemic) & 17 & 26 & 43 & 0.3953 \\
Total & 39 & 61 & 100 & 0.3900 \\
\hline
\end{tabular}

Odds Ratio 0.961 (95\% Cl 0.396-2.347)

$\mathrm{dL}$ vs. $132.9 \pm 42.5 \mathrm{mg} / \mathrm{dL}, \mathrm{p}$-value 0.000$), 2-\mathrm{hr}$ random blood glucose $(95.9 \pm 16.1 \mathrm{mg} / \mathrm{dl}$ vs. $183.5 \pm 67.5 \mathrm{mg} / \mathrm{dl}$, p-value 0.000$)$, and HDL $(58.5 \pm 16.0 \mathrm{mg} / \mathrm{dL}$ vs. $47.8 \pm 11.8$ $\mathrm{mg} / \mathrm{dL}$, p-value 0.000). Plasma adiponectin levels were not statistically different between normoglycemic (38 ng/dl) and hyperglycemic (33 ng/dl) individuals.

Out of the 100 subjects enrolled, 39 (39\%) were found to have the T45G adiponectin gene polymorphism. Twenty-two of the 57(38.59\%) hyperglycemic patients had the polymorphism while 17 of the 43(39.53\%) normoglycemic subjects had the polymorphism. There was no significant association found between genotypes of the T45G SNP and hyperglycemia (Table 2).

\section{DISCUSSION}

The T45G adiponectin gene polymorphism is the most frequent polymorphism in the $A D I P O Q$ gene. Studies have been undertaken with regard to its association with plasma adiponectin, and insulin resistance, metabolic syndrome, prevalence of diabetes mellitus, and diabetic nephropathy. ${ }^{33}$ However, the results are conflicting and inconsistent. An association of the T45G adiponectin gene polymorphism with diabetes has been seen in Caucasian populations ${ }^{26-28}$ however, the results are inconsistent among Asian populations.

The STOP-NIDDM trial conducted in Canada, Germany, Austria, Norway, Denmark, Sweden, Finland, Israel, and Spain, showed that the presence of a T45G defect is a predictor for conversion to T2D. ${ }^{34}$ Furthermore, in Spanish subjects T45G polymorphisms were noted to be associated with impaired glucose tolerance, along with the G/G genotype of SNP+276. ${ }^{35}$ It also appeared in Egyptians and Iraqis that there is an association between T45G SNPs and the development of T2D. ${ }^{36,37}$

In Saudis, neither T45G nor G762T adiponectin gene variants independently conferred any risks to metabolic conditions such as T2D, obesity, hypertension, or dyslipidemia. None of the genotypes were associated with either disease status, circulating adiponectin, or other anthropometric and biochemical factors analyzed such as glucose and insulin ${ }^{38}$ Disease entity seen with higher odds of occurrence with a T45G single-nucleotide polymorphism in the adiponectin gene is acute coronary syndrome events 
and has an effect on serum adiponectin levels among Arabs in Qatar. ${ }^{39}$

In a recent report among Indian Kashmiri population, the development of diabetes and metabolic syndrome was seen to have significant associations among those with T276G, compared to those who had T45G found to have non-statistically significant association. This suggests that the variant genotype $(\mathrm{GT}+\mathrm{TT})$ played an important role in etiology of T2D and metabolic syndrome. ${ }^{40}$ While in the Northeast (Assam), India SNP $+45 \mathrm{~T} / \mathrm{G}$ are risk factors for development of diabetes mellitus. This effect is independent from $\mathrm{BMI}$ and obesity. ${ }^{41}$

In Korean subjects, the T45G polymorphism of the adiponectin gene was not found to be an important determinant of T2D or insulin resistance. The study showed that there were no statistically significant differences in allele frequencies of SNP +45 comparing control with T2D subjects. The genotype distributions of the SNP had no association with the risk of T2D and metabolic parameters of insulin resistance. Plasma levels of adiponectin were also not statistically different in both control and T2D subjects. ${ }^{32}$

However, among the Japanese, SNPs in the adiponectin gene were associated with insulin resistance and T2D. It was found that the subjects with the $\mathrm{G} / \mathrm{T}$ or $\mathrm{G} / \mathrm{G}$ genotype at position 45 were at significantly increased risk for T2D (OR 1.41, 95\% CI 1.06-1.88; OR 1.70, 95\% CI $1.09-2.65$, respectively) compared with those having the T/T genotype. ${ }^{15,16}$

Among Chinese subjects, the association of tagging SNPs with the outcome of glycemic status in subjects with impaired glucose tolerance was examined in a 5-year prospective study. Fifteen polymorphisms in the $A D I P O Q$ were identified, ten of them constituting the tagging SNPs. At 5 years, $39.7 \%$ of the subjects with impaired glucose tolerance had regressed to normal glucose tolerance, $41.2 \%$ had persistent impaired glucose tolerance or impaired fasting glucose and $19.1 \%$ had developed diabetes. Only the T45G polymorphism was associated with persistent hyperglycemia at 5 years. ${ }^{29}$

The meta-analyses looking into T45G polymorphism with insulin resistance and blood glucose association have contradicting results. The $\mathrm{G}$ allele of the $A D I P O Q \mathrm{~T} 45 \mathrm{G}$ polymorphisms was associated with an overall significantly increased risk of T2D. Furthermore, in a subgroup analysis for Asian subjects, mainly Chinese, similar results were seen. ${ }^{42}$ In another study, having $\mathrm{T} 45 \mathrm{G}$ polymorphism gives an odds ratio of $1.43(1.01-2.03, \mathrm{p}=0.045)$ of developing diabetes and an odds ratio of $1.35(1.07-1.71, \mathrm{p}=0.012)$ of worsening glycemic status on long-term follow up.(33) However, another review found no significant associations even on subgroup analyses done in Asian races involving Japanese, Koreans, and Chinese. ${ }^{43}$

SNPs at $+276 \mathrm{G}>\mathrm{T}$ of the adiponectin gene in patients with T2D in Myanmar was associated with T2D, and low plasma adiponectin levels. Genotype frequencies (GG, GT,
TT) of SNP+276 in diabetic patients were $39 \%, 48 \%$, and $13 \%$, respectively. The GT and TT genotypes were more frequent in T2D patients (OR 1.98, 95\% CI, 1.10-3.55; $p=0.02$ and OR 4.07, 95\% CI, 1.34-12.3; $p=0.01$ ), respectively. The $\mathrm{T}$ allele of $\mathrm{SNP}+276$ was significantly associated with T2D (OR 1.96, 95\% CI, 1.27-3.01; $p=0.002$ ). ${ }^{44}$ Other SNPs such us T276G should be further explored as to its relationship to insulin resistance in the Filipino population.

T45G polymorphism investigations among patients with gestational diabetes mellitus revealed that the $\mathrm{G}$ allele and TG/GG genotype of $A D I P O Q$ were more frequent than the $\mathrm{T}$ allele and TT genotype in GDM patients compared to the controls $(\mathrm{p}<0.05)$. The risk of GDM was 2.5 fold higher in subjects with the TG/GG genotype to those with TT genotype. This study did not show any association between $\mathrm{SNP}+45 \mathrm{~T}>\mathrm{G}$ in the adiponectin gene and circulating adiponectin. ${ }^{45}$

Looking into states of insulin resistance like polycystic ovarian syndrome (PCOS) in Asians, G276T polymorphism of the $A D I P O Q$ reduced susceptibility to PCOS (OR: 0.68; 95\% CI: $0.60 \mathrm{e} 0.78 ; \mathrm{P}<0.001)$ while no significant association was observed for the $\mathrm{T} 45 \mathrm{G}$ polymorphism (OR: 1.07; 95\% CI: 0.93e1.24; PA 1/4 0.34). Subgroup analysis, on the other hand, showed significant associations among East Asians (OR: 0.69; 95\% CI: 0.57e0.82; PA < 0.001) for the G276T association. ${ }^{46}$

Metabolic syndrome and its relationship between the $\mathrm{SNP}+45 \mathrm{~T}>\mathrm{G}$ in the ADIPOQ gene were investigated in 450 Tunisian adults. The was no significant association between genotypes of T45G and the risk of MS. Those with MS had significantly higher levels of HOMA-IR $(p<0.001)$ and lower serum adiponectin concentrations $(\mathrm{p}<0.001)$ compared to controls. ${ }^{47}$ Other ADIPOQ gene variants I146T and G276T were studied on its association with obesity among adult women, however no relationship was established despite trend of decreased adiponectin with increased BMI, suggesting that adiponectin level may be a good indicator in BMI, but not $\mathrm{SNPs}^{48}$

Inconsistent data among the different populations could be attributable to inter-ethnic or population-based differences in polymorphisms of the adiponectin gene..$^{21,38}$ Despite numerous discordant studies to establish the relationship of the adipocytokine adiponectin with insulin resistance and the subsequent development of diabetes mellitus it is nevertheless important to explore, so as to open avenues for possible treatment targets. Diabetes mellitus continues to grow as an epidemic, and the molecular treatment targets are promising.

\section{CONCLUSION}

This is the first investigation in a Filipino population that determined the association of $\mathrm{T} 45 \mathrm{G}$ adiponectin gene polymorphism with hyperglycemia. In this pilot study involving 43 normoglycemic and 57 hyperglycemic 
Filipinos, no significant association between genotypes of the T45G SNP and hyperglycemia was observed. As the interplay of environmental and genetic factors play a huge role in disease management, the role of gene polymorphisms contributing to disease development is an unmet gap that needs further investigation. Adiponectin gene polymorphisms need to be further evaluated, and its role in the increased $\mathrm{T} 2 \mathrm{D}$ and other metabolic condition risks established. A similar study with a larger sample size is warranted to establish significant relationship between the different SNP genotypes and the occurrence of hyperglycemia in this population.

\section{Statement of Authorship}

EPP and ECDP were involved in all aspects of research work. ABU for the analysis and final version of the article.

\section{Author Disclosure}

All authors declared no conflicts of interest.

\section{Funding Source}

This research study was supported by the National Institutes of Health - University of the Philippines Manila, Pfizer, and AstraZeneca.

\section{REFERENCES}

1. Achari AE, Jain SK. Adiponectin, a therapeutic target for obesity, diabetes, and endothelial dysfunction. Int J Mol Sci. 2017 Jun; 18(6):1321.

2. Kadowaki T, Yamauchi T, Kubota N, Hara K, Ueki K, Tobe K. Adiponectin and adiponectin receptors in insulin resistance, diabetes, and the metabolic syndrome. J Clin Invest. 2006 Jul; 116(7):1784-92.

3. Kadowaki T, Yamauchi T. Adiponectin and adiponectin receptors. Endocr Rev. 2005 May; 26(3):439-51.

4. Ouchi N, Kihara S, Arita Y, Maeda K, Kuriyama H, Okamoto Y, et al. Novel modulator for endothelial adhesion molecules: Adipocytederived plasma protein adiponectin. Circulation. 1999 Dec; 100(25): 2473-6.

5. Ouchi N, Kihara S, Arita Y, Okamoto Y, Maeda K, Kuriyama H, et al. Adiponectin, an adipocyte-derived plasma protein, inhibits endothelial $\mathrm{NF}-\mathrm{KB}$ signaling through a cAMP-dependent pathway. Circulation. 2000 Sep; 102(11):1296-301.

6. Peters KE, Beilby J, Cadby G, Warrington NM, Bruce DG, Davis WA, et al. A comprehensive investigation of variants in genes encoding adiponectin (ADIPOQ) and its receptors (ADIPOR1/R2), and their association with serum adiponectin, type 2 diabetes, insulin resistance and the metabolic syndrome. BMC Med Genet. 2013 Jan; 14:15.

7. Arner P. The adipocyte in insulin resistance: Key molecules and the impact of the thiazolidinediones. Trends Endocrinol Metab. 2003 Apr; 14(3):137-45.

8. Pajvani UB, Scherer PE. Adiponectin: Systemic contributor to insulin sensitivity. Curr Diab Rep. 2003 Jun; 3(3):207-13.

9. Spranger J, Kroke A, Möhlig M, Bergmann MM, Ristow M, Boeing $\mathrm{H}$, et al. Adiponectin and protection against type 2 diabetes mellitus. Lancet. 2003 Jan; 361(9353):226-8.

10. Yamauchi T, Kamon J, Waki H, Terauchi Y, Kubota N, Hara K, et al. The fat-derived hormone adiponectin reverses insulin resistance associated with both lipoatrophy and obesity. Nat Med. 2001 Aug; 7(8):941-6.

11. Caselli C, D’Amico A, Cabiati M, Prescimone T, Del Ry S, Giannessi D. Back to the heart: The protective role of adiponectin. Pharmacol Res. 2014 Apr; 82:9-20.
12. Steyn FJ, Chen C. Adiponectin, second ed. Handbook of Biologically Active Peptides. Elsevier Inc.; 2013. pp. 983-989.

13. Lindsay RS, Funahashi T, Hanson RL, Matsuzawa Y, Tanaka S, Tataranni PA, et al. Adiponectin and development of type 2 diabetes in the Pima Indian population. Lancet. 2002 Jul; 360(9326):57-8.

14. Snehalatha C, Mukesh B, Simon M, Viswanathan V, Haffner SM, Ramachandran A. Plasma adiponectin is an independent predictor of Type 2 Diabetes in Asian Indians. Diabetes Care. 2003 Dec; 26(12):3226-9.

15. Nakashima R, Kamei N, Yamane K, Nakanishi S, Nakashima A, Kohno N. Decreased total and high molecular weight adiponectin are independent risk factors for the development of type 2 diabetes in Japanese-Americans. J Clin Endocrinol Metab. 2006 Oct; 91(10):3873-7.

16. Daimon M, Oizumi T, Saitoh T, Kameda W, Hirata A, Yamaguchi $\mathrm{H}$, et al. Decreased serum levels of adiponectin are a risk factor for the progression to type 2 diabetes in the Japanese population: The Funagata study. Diabetes Care. 2003 Jul; 26(7):2015-20.

17. Kim MJ, Yoo KH, Park HS, Chung SM, Jin CJ, Lee Y, et al. Plasma adiponectin and insulin resistance in Korean type 2 diabetes mellitus. Yonsei Med J. 2005 Feb; 46(1):42-50.

18. Duncan BB, Schmidt MI, Pankow JS, Bang H, Couper D, Ballantyne $\mathrm{CM}$, et al. Adiponectin and the development of type 2 diabetes: The atherosclerosis risk in communities study. Diabetes. 2004 Sep; 53(9):2473-8.

19. Araneta MRG, Barrett-Connor E. Adiponectin and ghrelin levels and body size in normoglycemic Filipino, African-American, and white women. Obesity. 2007 Oct; 15(10):2454-62.

20. Paz-Pacheco E, Lim-Abrahan MA, Sy RAG, Jasul G V., Sison CMC, Laurel AF. Adiponectin levels and its association with hyperglycaemia in adult Filipino participants in the 2003-04 National Nutrition and Health Survey. Diab Vasc Dis Res. 2009 Oct; 6(4):231-7.

21. Ouyang S, Cao D, Liu Z, Ma F, Wu J. Meta-analysis of the association of ADIPOQ G276T polymorphism with insulin resistance and blood glucose. Endocrine. 2014 Dec; 47(3):749-57.

22. Takahashi M, Arita Y, Yamagata K, Matsukawa Y, Okutomi K, Horie $\mathrm{M}$, et al. Genomic structure and mutations in adipose-specific gene, adiponectin. Int J Obes Relat Metab Disord. 2000 Jul; 24(7):861-8.

23. Vionnet N, Hani EH, Dupont S, Gallina S, Francke S, Dotte S, et al. Genomewide search for type 2 diabetes-susceptibility genes in French whites: Evidence for a novel susceptibility locus for earlyonset diabetes on chromosome 3q27-qter and independent replication of a type 2-diabetes locus on chromosome 1q21-q24. Am J Hum Genet. 2000 Dec; 67(6):1470-80.

24. Kissebah AH, Sonnenberg GE, Myklebust J, Goldstein M, Broman $\mathrm{K}$, James RG, et al. Quantitative trait loci on chromosomes 3 and 17 influence phenotypes of the metabolic syndrome. Proc Natl Acad Sci USA. 2000 Dec; 97(26):14478-83.

25. Hara K, Boutin P, Mori Y, Tobe K, Dina C, Yasuda K, et al. Genetic variation in the gene encoding adiponectin is associated with an increased risk of type 2 diabetes in the Japanese population. Diabetes. $2002 \mathrm{Feb}$; 51(2):536-40.

26. Vasseur F, Helbecque N, Dina C, Lobbens S, Delannoy V, Gaget $\mathrm{S}$, et al. Single-nucleotide polymorphism haplotypes in the both proximal promoter and exon 3 of the APM1 gene modulate adipocytesecreted adiponectin hormone levels and contribute to the genetic risk for type 2 diabetes in French Caucasians. Hum Mol Genet. 2002 Oct; 11(21):2607-14.

27. Fumeron F, Aubert R, Siddiq A, Betoulle D, Péan F, Hadjadj S, et al. Adiponectin gene polymorphisms and adiponectin levels are independently associated with the development of hyperglycemia during a 3-year period: The epidemiologic data on the insulin resistance syndrome prospective study. Diabetes. 2004 Apr; 53(4):1150-7.

28. Gu HF, Abulaiti A, Östenson CG, Humphreys K, Wahlestedt C, Brookes AJ, et al. Single nucleotide polymorphisms in the proximal promoter region of the adiponectin (APM1) gene are associated with Type 2 Diabetes in Swedish caucasians. Diabetes. 2004 Feb; 53(Suppl 1):S31-5. 
29. Tso AWK, Sham PC, Wat NMS, Xu A, Cheung BMY, Rong R, et al. Polymorphisms of the gene encoding adiponectin and glycaemic outcome of Chinese subjects with impaired glucose tolerance: A 5-year follow-up study. Diabetologia. 2006 Aug; 49(8):1806-15.

30. De Courten BV, Hanson RL, Funahashi T, Lindsay RS, Matsuzawa $\mathrm{Y}$, Tanaka $\mathrm{S}$, et al. Common polymorphisms in the adiponectin gene ACDC are not associated with diabetes in Pima Indians. Diabetes. 2005 Jan; 54(1):284-9.

31. Populaire C, Mori Y, Dina C, Vasseur F, Vaxillaire M, Kadowaki T, et al. Does the -11377 promoter variant of APM1 gene contribute to the genetic risk for Type 2 diabetes mellitus in Japanese families? Diabetologia. 2003 Mar; 46(3):443-5.

32. Lee YY, Lee NS, Cho YM, Moon MK, Jung HS, Park YJ, et al. Genetic association study of adiponectin polymorphisms with risk of Type 2 diabetes mellitus in Korean population. Diabet Med. 2005 May; 22(5):569-75.

33. Leu HB, Chung CM, Lin SJ, Jong YS, Pan WH, Chen JW. Adiponectin gene polymorphism is selectively associated with the concomitant presence of metabolic syndrome and essential hypertension. PLoS One. 2011; 6(5):e19999.

34. Zacharova J, Chiasson JL, Laakso M. The common polymorphisms (Single Nucleotide Polymorphism [SNP] +45 and SNP +276) of the adiponectin gene predict the conversion from impaired glucose tolerance to type 2 diabetes: The STOP-NIDDM trial. Diabetes. 2005 Mar; 54(3):893-9.

35. González-Sánchez JL, Zabena CA, Martínez-Larrad MT, FernandezPérez C, Pérez-Barba M, Laakso M, et al. An SNP in the adiponectin gene is associated with decreased serum adiponectin levels and risk for impaired glucose tolerance. Obes Res. 2005 May; 13(5):807-12.

36. Ali NA, Qaddoori AA. Association of +45 (T/G) Polymorphism in the adiponectin gene with Type 2 Diabetes Mellitus in Iraqi patients. IJABR. 2013; 3(4):549-52.

37. Ooda SA, El-Belbesy MF, Hassanein NM, Elgaddar OH, Bachlah HM. Assessment of the association of the adiponectin gene singlenucleotide polymorphism 45T/G with type 2 diabetes mellitus in Egyptian diabetic patients. Egypt J Obes Diabetes Endocrinol. 2016; 2(1):23-30.

38. Al-Daghri NM, Al-Attas OS, Alokail MS, Alkharfy KM, Hussain $\mathrm{T}$, Yakout S, et al. Adiponectin gene polymorphisms (T45G and G276T), adiponectin levels and risk for metabolic diseases in an Arab population. Gene. 2012 Feb; 493(1):142-7.
39. Rizk NM, El-Menyar A, Marei I, Sameer M, Musad T, Younis $\mathrm{D}$, et al. Association of adiponectin gene polymorphism (+T45G) with acute coronary syndrome and circulating adiponectin levels. Angiology. 2013 May; 64(4):257-65.

40. Farooq R, Majid S, Ahmad Bhat S, Amin S, Hayat Bhat M, Ahmad Wani $\mathrm{H}$, et al. Association of adiponectin gene polymorphism with type 2 diabetes and metabolic syndrome. Transl Metab Syndr Res. 2018 Dec; 1:39-47.

41. Kordafshari M, Kordafsharin M, Deka M, Khandouzi M, Kashyap P, Kumari N. Adiponectin Gene Polymorphism SNP + 45 T / G in Type 2 Diabetic Patients in Assam, India. Int J Res Appl Sci Eng Technol. 2016 Mar; 4(III):174-6.

42. Fan Y, Wang K, Xu S, Chen G, Di H, Cao M, et al. Association between adipoq $+45 t>G$ polymorphism and type 2 diabetes: $A$ systematic review and meta-analysis. Int J Mol Sci. 2015 Jan; 16(1):704-23.

43. Cao D, Ouyang S, Liu Z, Ma F, Wu J. Association of the ADIPOQ T45G polymorphism with insulin resistance and blood glucose: A meta-analysis. Endocr J. 2014; 61(5):437-46.

44. Yu KT, Maung KK, Thida A, Myint T. Single nucleotide polymorphism at $+276 \mathrm{~g}>\mathrm{T}$ of the adiponectin gene and plasma adiponectin level in Myanmar type 2 diabetic patients. J ASEAN Fed Endocr Soc. 2018 Nov; 33(2):160-4.

45. Takhshid MA, Haem Z, Aboualizadeh F. The association of circulating adiponectin and $+45 \mathrm{~T} / \mathrm{G}$ polymorphism of adiponectin gene with gestational diabetes mellitus in Iranian population. J Diabetes Metab Disord. 2015; 14:30.

46. Tiongco RE, Cabrera FJ, Clemente B, Flake CC, Salunga MA, Pineda-Cortel MR. G276T polymorphism in the ADIPOQ gene is associated with a reduced risk of polycystic ovarian syndrome: A metaanalysis of Asian population. Taiwan J Obstet Gynecol. 2019 May; 58(3):409-16.

47. Sahli S, Khlifi L, Jaballah A, Khelil S, Bouzidi N, Chahed H, et al. Evaluation of serum adiponectin and ADIPOQ $+45 \mathrm{t}>\mathrm{G}$ polymorphism with metabolic syndrome in Tunisian population. Int J Pharm Sci Res. 2017; 8(3):1294-1300.

48. Khabour OF, Alomari MA, Abu Obaid AA. The Relationship of adiponectin level and ADIPOQ gene variants with BMI among young adult women. Dermatoendocrinol. 2018; 10(1):e1477902. 